\title{
Demarcation problem in fusuline classification: A case for Verella/Eofusulina discrimination
}

\author{
Katsumi UENO ${ }^{1,2 *}$ \& Elisa VILLA ${ }^{2}$ \\ ${ }^{1}$ Department of Earth System Science, Fukuoka University, Fukuoka 814-0180, Japan; katsumi@fukuoka-u.ac.jp \\ ${ }^{2}$ Departamento de Geología, Universidad de Oviedo, c/ Jesús Arias de Velasco, s/n, 33005 Oviedo, Spain; evilla@geol.uniovi.es \\ * Corresponding author
}

Ueno, K. \& Villa, E. 2018. Demarcation problem in fusuline classification: A case for Verella/Eofusulina discrimination. [Problemas en la clasificación de fusulinas: el ejemplo de la distinción entre Verella y Eofusulina]. Spanish Journal of Palaeontology, 33 (1), 215-230.

Manuscript received 4 December 2017

Manuscript accepted 5 March 2018

(C) Sociedad Española de Paleontología ISSN 2255-0550

\begin{abstract}
The eofusulinin genera Verella and Eofusulina formed an important lineage among fusulines to define the Bashkirian/ Moscovian transitional interval in the Pennsylvanian (Upper Carboniferous) subsystem. We studied morphologies of Verella transiens, a highly evolved form in the genus, and the first Eofusulina species from the Los Tornos section in the Cantabrian Zone of northern Spain, to understand the discriminating diagnosis of these two genera. We conclude that Eofusulina is distinguishable from Verella in having stronger septal fluting, lesser development of secondary deposits, generally larger proloculus, absence of early tightly coiled volutions, and with some lesser extent slightly larger diameter of shell and absence of polar torsion. No single morphological character provides a reliable criterion to distinguish the two genera, but rather only a combination of all these morphological criteria enables reliable generic discrimination. In order to better understand the morphology, we emphasise the usefulness of non-oriented specimens in this study. They have potential to show some morphological features that are sometimes not easy to perceive based only on well-oriented axial and sagittal sections. In regional biostratigraphic aspects, we propose a minor modification on the FAD of Eofusulina in the Los Tornos section, and
\end{abstract}

\section{RESUMEN}

La evolución de Verella hacia Eofusulina presenta un gran interés para caracterizar paleontológicamente el intervalo de transición entre los pisos Bashkiriense y Moscoviense (Pensilvánico/Carbonífero superior). En este trabajo hemos estudiado detalladamente la morfología de Verella transiens, especie avanzada de este género, en ejemplares procedentes de la sección de Los Tornos (Zona Cantábrica, norte de España). El objetivo ha sido fijar con claridad los criterios de separación entre Verella y Eofusulina, concluyendo que Eofusulina se puede distinguir de Verella por presentar plegamiento septal más intenso, menor desarrollo de los depósitos secundarios, prolóculo generalmente de mayor talla, ausencia de arrollamiento apretado en las vueltas iniciales, y, en menor grado, diámetro de la concha ligeramente mayor y ausencia de torsión polar. Ninguno de estos criterios es suficiente por sí mismo para distinguir estos dos géneros, sino que una identificación fiable ha de basarse en la combinación de los anteriormente expuestos $y$, en este sentido, destacamos la gran utilidad que pueden presentar las secciones no perfectamente axiales, ya que muestran rasgos que, con frecuencia, pasan desapercibidos en las secciones axiales y sagitales. Con respecto a la bioestratigrafía de la sección de Los Tornos, señalamos la primera aparición de Eofusulina 
lower it about $5 \mathrm{~m}$ stratigraphically. We also perform a comprehensive taxonomic review of Verella and Eofusulina. Two replacement names, Verella zhenanensis and $V$. ivanovae, are proposed for Pseudowedekindellina fusiformis Sun and $V$. fusiformis Ivanova, which are subjective and objective junior synonyms of $V$. fusiformis Bensh, respectively. Moreover, we deem $V$. varsanofievae as a correct original spelling of the type species of Verella, in accordance with the International Code of Zoological Nomenclature.

Keywords: Carboniferous, Pennsylvanian, fusuline morphology, thin section, taxonomy. unos $5 \mathrm{~m}$ por debajo del nivel que se había indicado en trabajos anteriores. También hemos realizado una revisión de la taxonomía de estos dos géneros, proponiendo los nombres Verella zhenanensis y $V$. ivanovae para las especies descritas originalmente como Pseudowedekindellina fusiformis Sun y V. fusiformis Ivanova, ya que ambas deben ser consideradas como sinónimos de Verella fusiformis Bensh. Finalmente, de acuerdo con los requisitos establecidos en el Código de Nomenclatura Zoológica, se propone $V$. varsanofievae como nombre correcto de la especie tipo del género.

Palabras clave: Carbonífero, Pensilvánico, morfología de fusulinas, lámina delgada, taxonomía.

\section{INTRODUCTION}

Fusulines are the first group of larger foraminifera to appear in the history of foraminiferal evolution (e.g., BouDagherFadel, 2008). They constructed many chambers through growth, which are systematically arranged in an enrolling manner around the constant axis of coiling. Because of their innate large test size, commonly several millimetres in length but sometimes up to a few centimetres, planispiral chamber arrangement, and more complicated internal shell structures compared to rather simple outer morphologies, as well as their exclusive occurrence from consolidated limestones, fusulines are usually studied with thinsectioned specimens under the microscope. For better taxonomic investigation and identification, it is especially important to prepare oriented specimens, such as axial and sagittal (cross) sections, which are cut through the first chamber (proloculus) in parallel or perpendicular to the axis of coiling (Dunbar \& Henbest, 1942). In making fusuline thin sections, tangential and parallel sections (which cut shells in parallel or perpendicular to the axis of coiling but do not pass through the proloculus) are considered to have relatively minor importance, and oblique sections which cut fusuline shells randomly are even less valuable.

Thin-section study of fusulines, based especially on abundant axial and sagittal sections, provides a firm basis to clarify internal shell morphologies and their ontogenetic changes through growth (Dunbar \& Henbest, 1942; Miklukho-Maklay et al., 1959). Accordingly, fusuline micropalaeontologists usually pay more attention to study such well-oriented specimens and tend to illustrate them more in their publications. However, some threedimensional morphological characters can be difficult to understand when studying only oriented specimens. The nature and intensity of septal fluting is one such character that the study of non-oriented specimens has provided a broader understanding.
Moreover, a number of morphological characters often change continuously in varied degrees not only within the same species (e.g., Ozawa, 1975) but also between two phylogenetically consecutive taxa (e.g., Davydov, 1990). Such phyletic gradualism has been documented in various clades in fusuline foraminifera (e.g., Ozawa, 1970; Davydov, 1988; Groves, 2005), and it can make the discrimination of closely-related species quite difficult.

The two early fusuline genera Verella and Eofusulina appeared around the Bashkirian/Moscovian boundary interval. They both have elongate to highly elongate fusiform shells (Fig. 1) which are distinctive among fusuline genera seen in this interval, and formed a single evolutionary continuum (Miklukho-Maklay et al., 1959; Leven, 1979; Ivanova, 2008). Because of these morphological, phylogenetic, and biostratigraphic peculiarities, the Verella-Eofusulina transition is considered to be a potential marker that can assist in the recognition of the Bashkirian/Moscovian boundary in the Pennsylvanian (Upper Carboniferous) subsystem (Ivanova, 2008, 2015a; Groves \& Task Group, 2011). It is considered that these two genera differ mainly in the degree of septal fluting. Septal fluting in Verella usually is weak and restricted to the poles and lateral slopes, whereas in Eofusulina septal fluting is stronger and extends across the entire length of the test (Groves \& Task Group, 2011). In addition to the difference in the intensity of septal fluting, Eofusulina generally has a larger shell with a larger proloculus and lesser-developed secondary deposits than Verella. Because these characters changed gradually in the course of phylogenetic evolution in the Verella-Eofusulina lineage, it is known to occur transitional forms, such as $V$. transiens van Ginkel \& Villa in van Ginkel (1987) from the Cantabrian Zone of Northern Spain, which possess shell characters intermediate between Verella and Eofusulina. This makes morphological distinction of these two genera somewhat controversial in some cases.

The Los Tornos section in the Cantabrian Zone of northern Spain was recently reported by Villa \& Merino- 


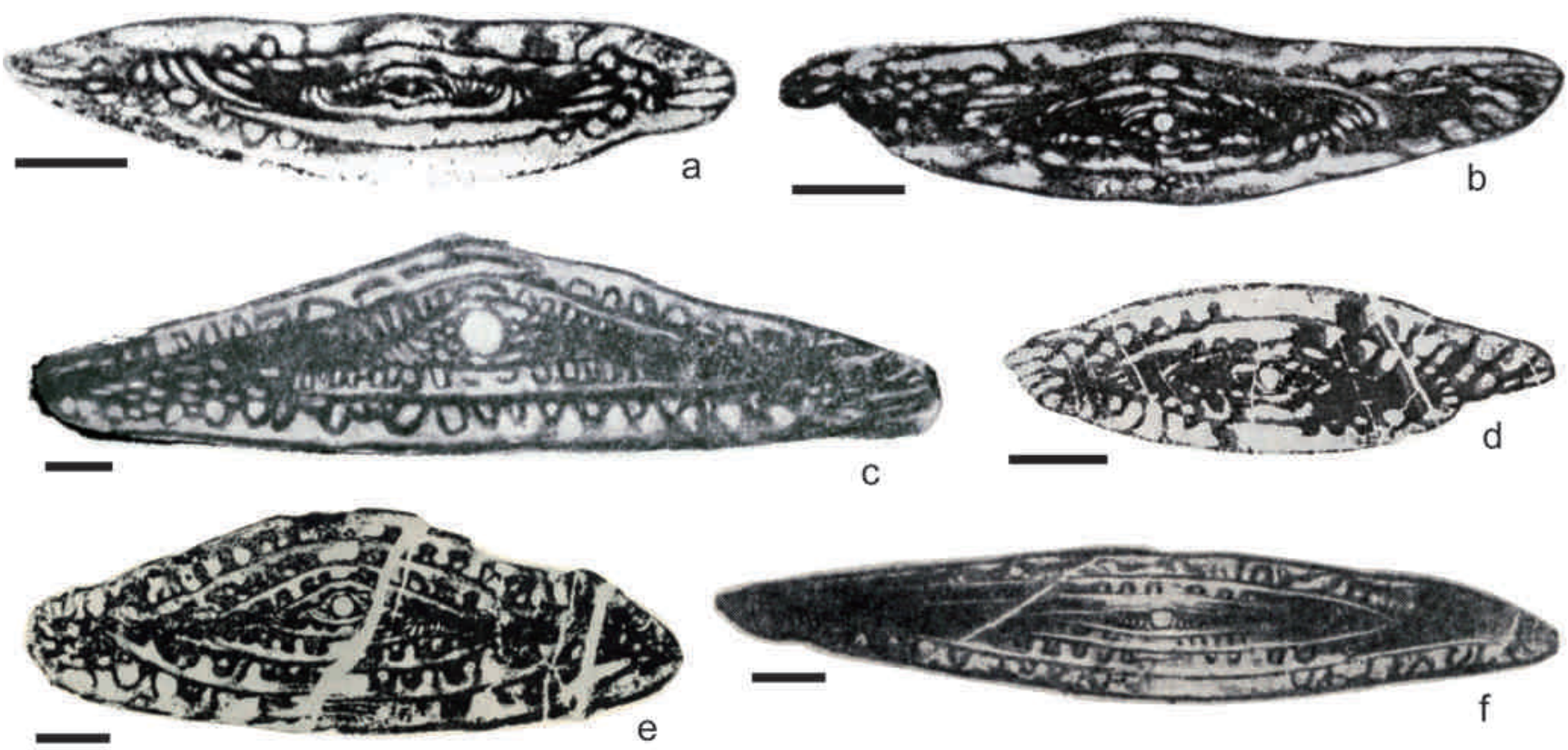

Figure 1. Type species of Verella and Eofusulina, and their synonymous genera. a) Verella varsanofievae Dalmatskaya, 1951 (specific name originally spelled as warsanofievie; see text for details), the type species of Verella Dalmatskaya, 1951. b) Pseudowedekindellina prolixa Sheng, 1958, the type species of Pseudowedekindellina Sheng, 1958 (=Verella). c) Fusulina triangula Rauzer-Chernousova \& Beljaev in Rauzer-Chernousova et al., 1936, the type species of Eofusulina RauzerChernousova in Rauzer-Chernousova et al., 1951. d) Akiyoshiella ozawai Toriyama, 1953, the type species of Akiyoshiella Toriyama, 1953 (=Eofusulina). e) Eofusulina figurata Ivanova in Chuvashov \& Ivanova, 1980, the type species of Postverella Ivanova, 2008 (=Eofusulina). f) Eofusulina (Paraeofusulina) trianguliformis Putrja, 1956, the type species of Eofusulina (Paraeofusulina) Putrja, 1956. All scale bars equal to $0.5 \mathrm{~mm}$.

Tomé (2016) as showing a good and relatively continuous fusuline record across the Bashkirian/Moscovian boundary. Importantly, the section has both occurrences of advanced Verella, V. transiens, and the early Eofusulina at several levels (Villa \& Merino-Tomé, 2016, fig. 5), so it is promising to investigate the problem on how to put the morphological boundary between these two genera. These authors presented a number of good axial-sectioned fusuline specimens around the boundary interval. With respect to $V$. transiens, however, they did not show specimens from its last few occurrences.

In this study, we reexamined materials from the Los Tornos section used in Villa \& Merino-Tomé (2016), in order to make clear morphological differentiation between the genera Verella and Eofusulina. Our investigation revealed that randomly oriented specimens, which are usually considered less important for fusuline taxonomy, can be utilised for understanding some key morphological features of these genera. Moreover in the last part of this article, we make a taxonomic review of Verella and Eofusulina, in consideration of the present state that quite few papers made taxonomic overview of these genera. All the illustrated specimens from the Los Tornos section are deposited in the micropalaeontological collection of the Departamento de Geología, Universidad de Oviedo, Spain.

\section{STRATIGRAPHY AND STUDY MATERIALS}

The study materials were originally prepared for a study of the Los Tornos section by Villa \& Merino-Tomé (2016). The geological background of the section and the details of stratigraphy and fusuline faunal succession are described in that paper. We briefly summarise some important geological outlines of the section below.

The Los Tornos section is situated at about $30 \mathrm{~km}$ southeast of Oviedo, in the Central Asturian Coalfield, northern Spain (Fig. 2a). Geologically it is in the middle of the Bodón-Ponga Unit in the central part of the Cantabrian Zone (Alonso et al., 2009). The section is about $850 \mathrm{~m}$ thick, and consists of the Fresnedo, Levinco, and Llanón units in ascending order (Fig. 2b), which represent informal (local) stratal packages conventionally used for coal-mining industry. In this section, there are nine limestone intervals, including the 50-m-thick Peña Redonda Limestone at the base of the Levinco unit. The Los Tornos section consists entirely of marine siliciclastics, marls, and limestones, and represents cyclic sedimentation showing distinctive transgressive-regressive cycles (cyclothem). There are several levels of subaerial exposures with the occurrence of paleosols, which correspond to recognizable hiatuses. 
The samples examined in this study came from the second, third, fifth, sixth, and seventh limestone intervals from the base of the section (Fig. 2b).

\section{OBSERVATIONS}

We examined thin sections from totally 13 samples (LT25, LT-26, LT-27, LT-28, LT-29, LT33, LT36, LT42, LT44, LT-45, LT-47, LT-49, and LT-51; Fig. 2b), which contain eofusulinin species with elongate to highly elongate fusiform shells. Of them, Villa \& Merino-Tomé (2016) illustrated axial sections of Verella transiens from LT-26, LT-27, and LT-29, and those of Eofusulina sp. from LT45, LT-49, and LT-51. In this study, we also paid special attention to observe non-oriented specimens in order to understand the entire morphological features of these species.

\subsection{Samples LT-25 to LT-29}

These five samples were collected in the second limestone interval from the base of the section (Fig. 2b). All the Verella transiens specimens illustrated by Villa \& MerinoTomé (2016) are from this limestone member (samples LT-26, LT-27, and LT-29), where they were associated with species of Profusulinella and Aljutovella. As they described, those specimens have very elongate fusiform shells with bluntly pointed polar ends, and broadly arched central part. Chomata are present from the first to penultimate or the last volutions, and supplementary deposits are well recognised especially in the axial regions, but do not fill the entire chambers. They have moderatesized proloculus (90-170 $\mu \mathrm{m}$ in outside diameter). Septa are unfluted in the early volutions, and are moderately but not very regularly fluted in the outer ones. All these features well fit with the diagnosis of $V$. transiens originally reported by van Ginkel (1987) from the Lena Formation near Puebla de Lillo, about $30 \mathrm{~km}$ to the southeast of Los Tornos, in the same Bodón-Ponga Unit in the central part of the Cantabrian Zone.

We supplement here further observations with additional illustrations from these sample levels. In two sagittal sections (Figs 3g, 3j), a relatively small proloculus is followed by one and a half to two, slightly tightly coiled early volutions, which make an indistinct juvenarium. A similar feature is also seen in some axial sections illustrated by Villa \& Merino-Tomé (2016). Six tangential sections (Figs 3a-3d, 3h-3i), which cut variously distant positions from the proloculus, demonstrate the degree of septal fluting and the approximate positions where septa are fluted. Some of these specimens show that septa are moderately fluted along lateral slopes, forming incipient septal chamberlets (Figs 3b-3c), but septal loops are semicircular and only as high as half the chamber height (e.g., Figs 3b, 3d, 3h-i). Two other specimens (Figs 3a, 3e) exhibit septa that are unfluted at the polar end of the shells. Moreover, they clearly show polar torsion in the very end of the polar region.

In two sagittal sections (Figs 3g, 3j), we can observe that septa are numerous (number of septa counted to be 32 in the fifth volution in the specimen illustrated on Figure $3 \mathrm{j}$ ) and they are rather narrowly spaced in this species. Judging from the presence of well-developed secondary deposits of chomata at the base of volutions, the specimens on Figures $3 \mathrm{f}$ and $3 \mathrm{k}$ are parallel sections that probably cut around the position of the one-third from the proloculus to the axial end, almost perpendicularly to the coiling axis. In these sections, septa are very narrowly spaced and often weakly bending anteriorly (and sometimes posteriorly) at the lower part of the volutions, but a peak and a trough of two adjacent fluted septa seldom join each other, forming a peculiar "V-shaped" connection (compare these specimens to that illustrated on Figure 3v obtained from a much higher level in the sixth limestone interval, which develops a greater number of these "V-shaped" features, suggesting a stronger degree of septal fluting).

\subsection{Sample LT-33}

This level corresponds to the upper part of the limestone interval from which samples LT-25 to LT-29 were collected (Fig. 2b). In this sample, Villa \& Merino-Tomé (2016) reported the occurrence of Verella transiens, but did not illustrate any specimens. Only one, probably immature tangential section, showing well-developed axial fillings, is available from this sample (Fig. 31). It has weakly fluted septa on the lateral slopes and plane septa at the very end of the polar region, in probably the third (or third and a half?) volution. This specimen is very similar to that illustrated on Fig. 3h from sample LT-29.

\subsection{Sample LT-36}

Villa \& Merino-Tomé (2016) also cited the occurrence of Verella transiens without illustration from this level, in the lower part of the third limestone interval from the base of the Los Tornos section (Fig. 2b). One tangential section is examined in the present study (Fig. 3m). Though poorly oriented, this specimen has somewhat similar features as those illustrated on Figures $3 \mathrm{~d}$ and $3 \mathrm{i}$ from samples LT26 and LT27, in having a very elongate shell, dense axial fillings in the polar region, plane septa in the central part of the early volutions, and weakly fluted septa on the lateral slopes. 


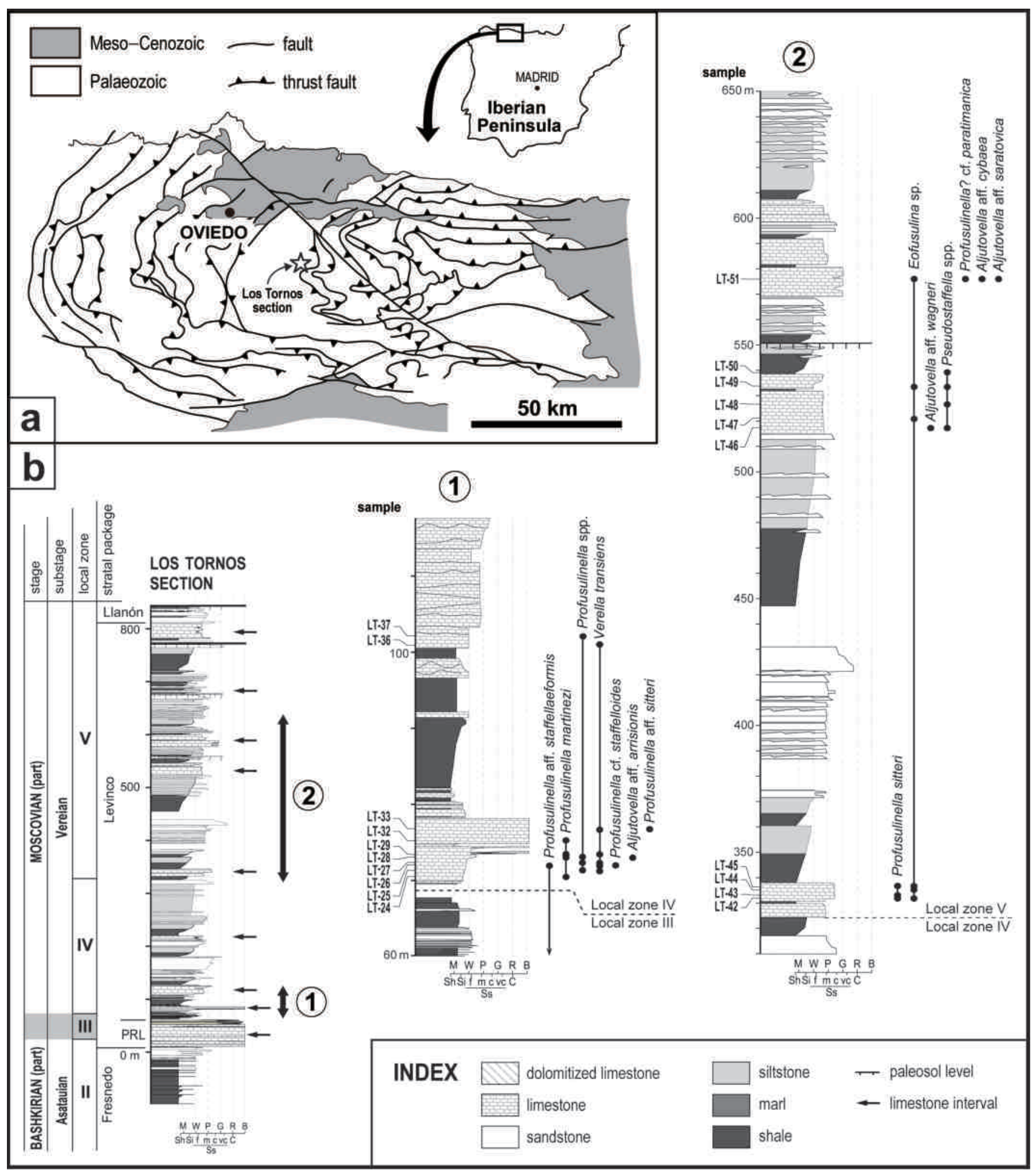

Figure 2. Index map and stratigraphic logs of the Los Tornos section. a) Structural sketch and the distribution of Paleozoic strata in the Cantabrian Zone of northern Spain, with the location of the Los Tornos section (star mark). b) Stratigraphy, major fusuline occurrences, and sample levels of the Los Tornos section, with the subdivision of local biostratigraphic zones and their correlation (adapted from Villa \& Merino-Tomé, 2016). PRL: Peña Redonda Limestone. Some occurrences of Verella transiens and Eofusulina sp. are modified from the original, following the observation of this study, and accordingly the boundary between local zones IV and V is slightly lowered. Shaded band (corresponding to local zone III) represents the Bashkirian/Moscovian transitional interval (see Villa \& Merino-Tomé, 2016 for further details). Subdivision of limestone microfacies and scale for grain size; M: lime mudstone; W: wackestone; P: packstone; G: grainstone; R: rudstone; B: boundstone; Sh: shale; Si: siltstone; Ss: sandstone (f: fine; m: medium; c: coarse; vc: very coarse); C: conglomerate. 

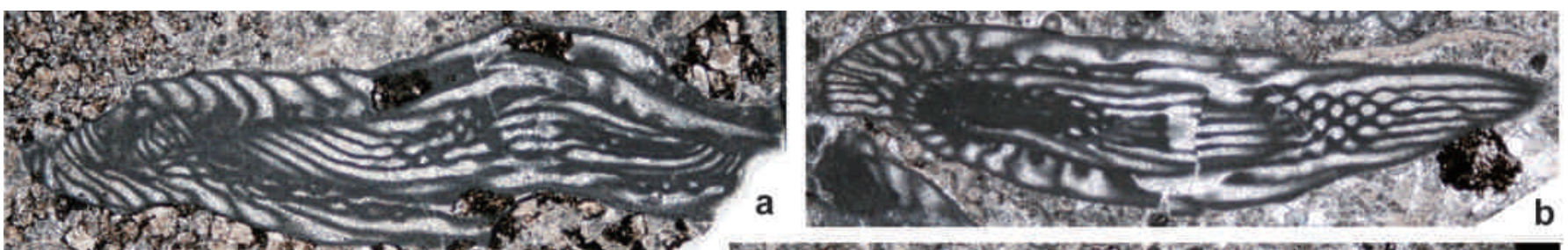

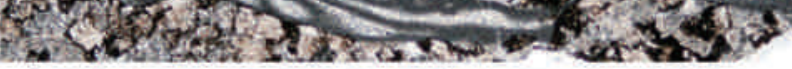
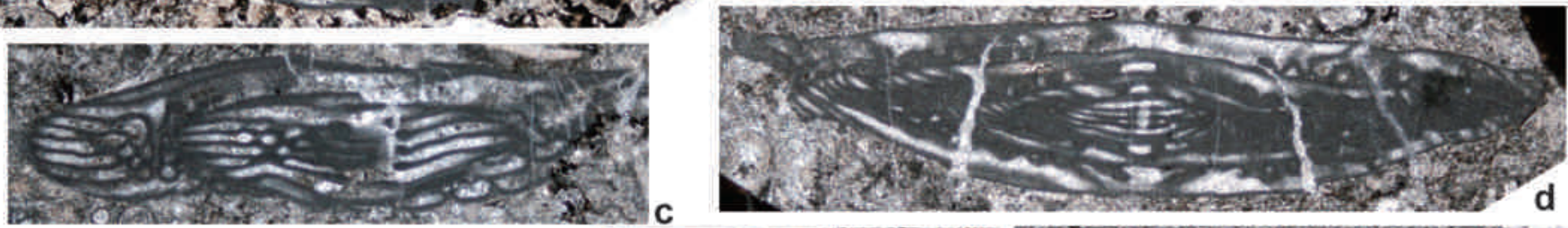

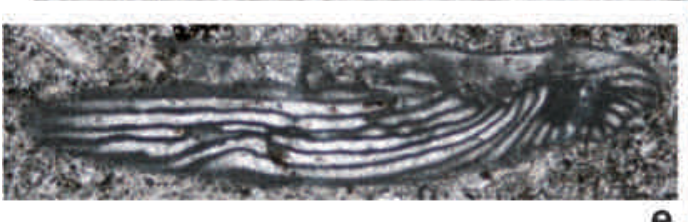

e

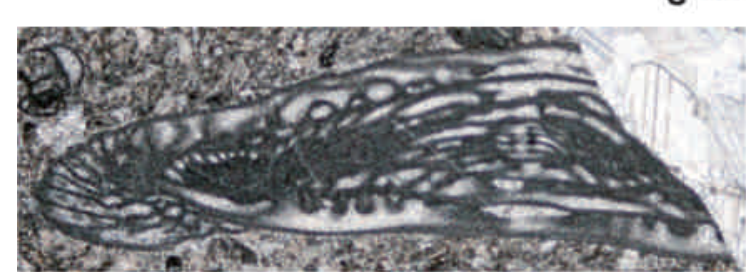

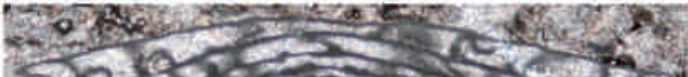

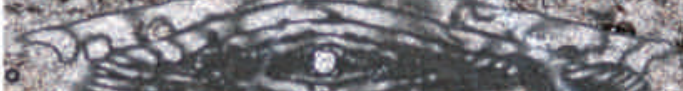
(1)

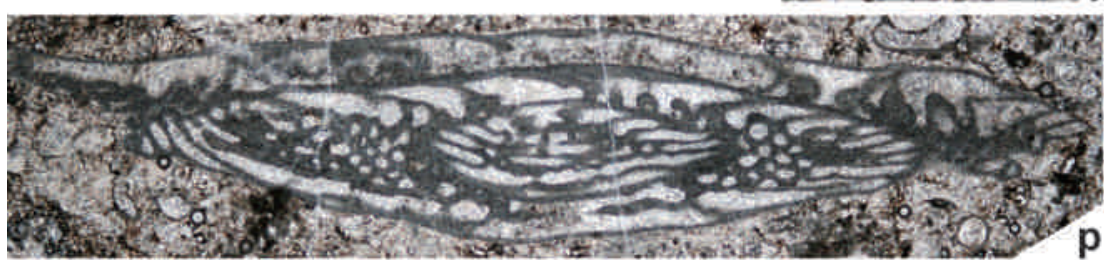

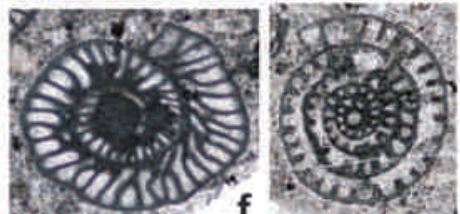

9 1
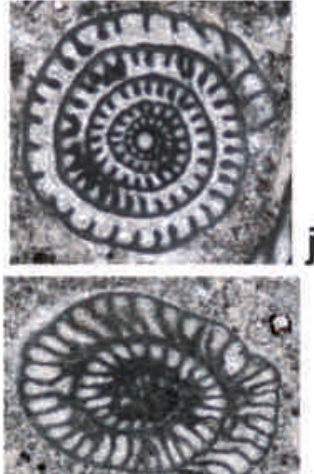

redines:

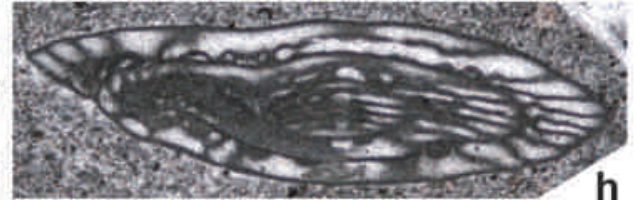

h

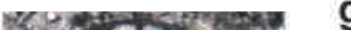

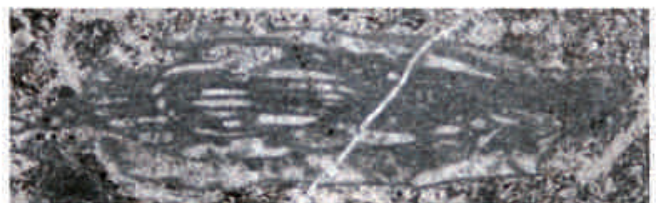

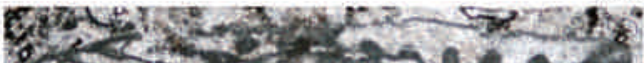

$\mathrm{m}$

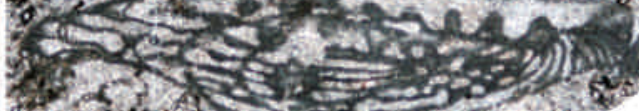

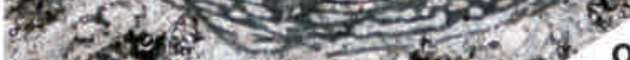

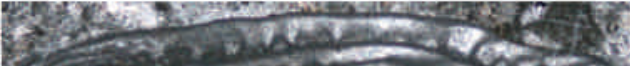
Solger:

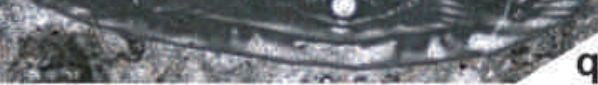

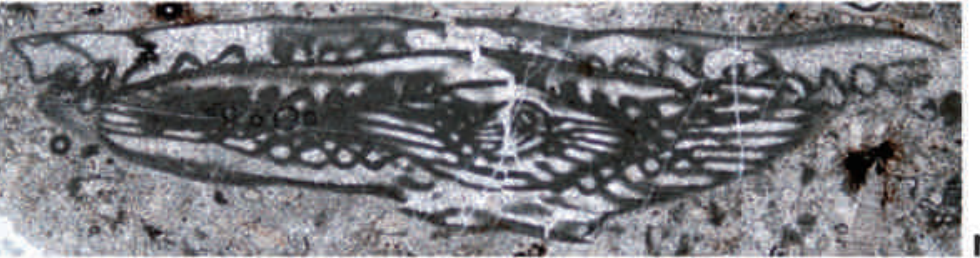

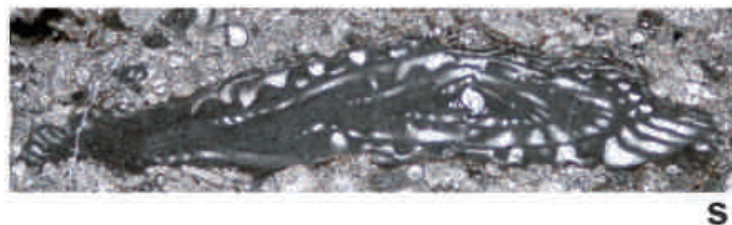

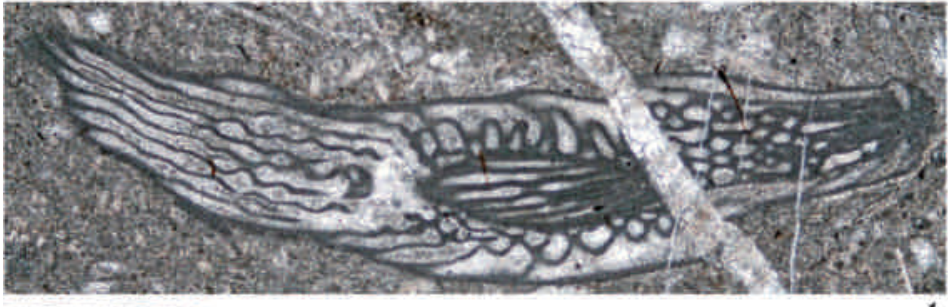
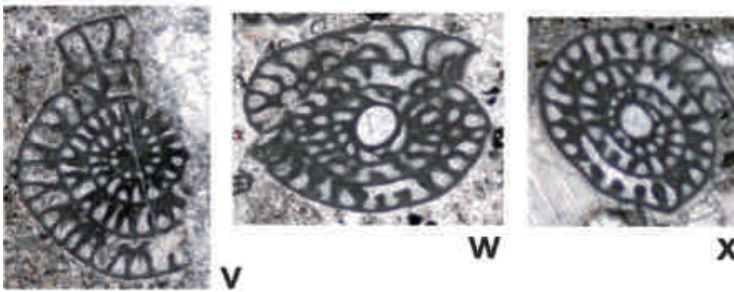

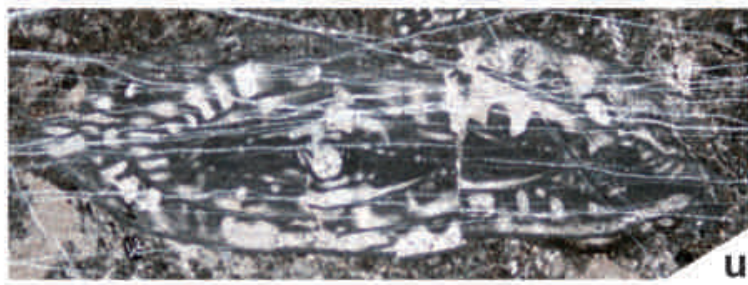

t

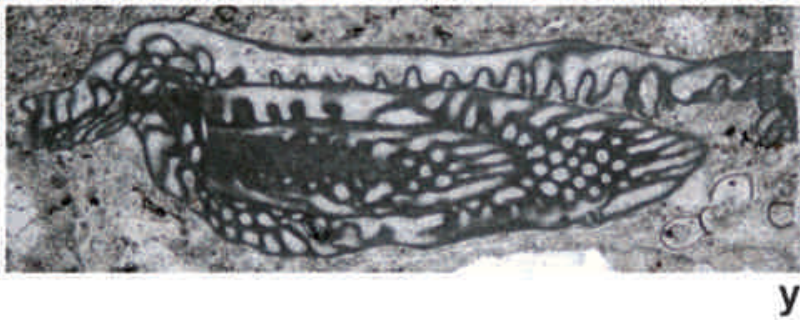




\subsection{Samples LT-42 and LT-44}

These two samples came from the upper part of the fifth limestone interval from the base of the section. They correspond to at 330-340 m levels from the base of the section, and about $240 \mathrm{~m}$ stratigraphically higher than the last, lower, Verella-bearing sample (LT-36; Fig. 2b). In the present two levels, the occurrence of Verella transiens was documented by Villa \& Merino-Tomé (2016) but specimens were not illustrated.

In fact, two, probably non-full-matured specimens (Figs 3n, 3q) are reminiscent of axial sections of $V$. transiens, except for the weaker development of chomata and slightly more intense septal fluting in the former. But other associated eofusulinin specimens in these samples (Figs 3o-3p, 3r-3s) clearly demonstrate stronger septal fluting, especially in the lateral slopes and polar regions, sometimes forming high and narrow (and occasionally irregular) septal loops. In tangential sections, septal chamberlets made by the connection of neighbouring peaks and troughs out of phase are well exhibited (Fig. 3p). Thus overall, it can be said that septa become more intensely fluted in these specimens compared to those of eofusulinines from the second and third limestone intervals. Moreover, these specimens have less developed secondary deposits, shown as axial fillings and chomata, compared to eofusulinin ( $V$. transiens) specimens in lower sample levels (see also Villa \& Merino-Tomé, 2016, fig. 14 for comparison).

\subsection{Sample LT-45}

This is the level of the first Eofusulina species by Villa \& Merino-Tomé (2016), from which one axial section was illustrated (Villa \& Merino-Tomé, 2016, fig. 14.11). It is also in the same fifth limestone interval from which samples LT-42 and LT44 were collected (Fig. 2b). One additional axial section is examined in this study (Fig. $3 \mathrm{u})$. Both axial-sectioned specimens have four and a half volutions and large proloculi (200 and $220 \mu \mathrm{m}$ in outside diameter, respectively), and expand regularly from the first volution, lacking a tightly coiled inner part. They are characterised by relatively regularly and strongly fluted septa and weaker axial fillings.

\subsection{Samples LT-47 to LT-51}

These samples were collected from the sixth and seventh limestone intervals from the base of the section, which are closely situated to each other stratigraphically but separated by a distinct paleosol horizon (Fig. 2b). Villa \& MerinoTomé (2016) reported Eofusulina from LT-47, LT-49, and LT51, from which two axial sections were illustrated from the latter two sample levels. Here we additionally illustrate two tangential (Figs 3t, 3y), two sagittal (Figs 3w, 3x), and one parallel (Fig. 3v) sections. The tangential sections clearly possess stronger septal fluting, which extends to the lateral slope and the middle part of shell, with the septa forming high and narrow septal loops. In the parallel section, the "V-shaped" (or "Y-shaped" when septal fluting is stronger) connection of two successive septa are more often observed compared to Verella transiens from the second limestone interval, suggesting that the specimens from the sixth and seventh limestone intervals have definitely stronger septal fluting. Sagittal-sectioned specimens have large proloculi (220 and $250 \mu \mathrm{m}$ in outside diameter), followed by regularly expanding volutions, and do not show juvenile tight coiling that can be seen in $V$. transiens (Figs 3g, 3j; and see also specimens illustrated on fig. 14 in Villa \& Merino-Tomé, 2016).

\section{DISCUSSION AND CONCLUDING REMARKS}

The above-mentioned observations with respect to the Verella-Eofusulina lineage from the Los Tornos section indicate that, as Villa \& Merino-Tomé (2016) concluded, the eofusulinin specimens from the second limestone interval of the section (samples LT-25 to LT-29) are assignable to Verella transiens, which is considered as a highly evolved member of the genus Verella (van Ginkel, 1987). This interval denotes the basal part of the local zone IV (Villa \& Merino-Tomé, 2016) (Fig. 2b). Although they are poorly oriented, two tangential sections obtained from overlying levels (samples LT-33 and LT-36) in the same and next adjacent limestone intervals, examined in this study are also highly probably included in the

Figure 3. Eofusulinin specimens from the Los Tornos section of northern Spain (materials used in Villa \& Merino-Tomé, 2016, but not illustrated in that paper). (a-m) Verella transiens van Ginkel \& Villa in van Ginkel, 1987. (a, g, k) Specimens from sample LT-25: a) tangential section; g) sagittal section; k) parallel section. (b-d, j) Specimens from LT-26: b-d) tangential sections; j) sagittal section. (e-f, i) Specimens from sample LT-27: e) oblique section; f) parallel section; i) tangential section. h) Specimen from sample LT-29 (tangential section). l) Specimen from sample LT-33 (tangential section). m) Specimen from sample LT-36 (tangential section). (n-y) Eofusulina sp. n-p) Specimens from sample LT-42: n) axial section, o-p) tangential sections. (q-s) specimens from sample LT-44: q, s) axial sections; r) tangential section. t) Specimen from LT49 (tangential section). u) Specimen from sample LT-45 (axial section). (v, $\mathbf{x}-\mathbf{y})$ specimens from sample LT-47: v) parallel section; $\mathbf{x}$ ) sagittal section; y) tangential section. w) Specimen from sample LT-51 (sagittal section). 
same species (Fig. 2b). All these specimens suggest that septa in $V$. transiens are moderately fluted along lateral slopes (e.g., Figs 3d, 3h, 3i) but become unfluted toward both the median part of shell and polar ends (Figs 3ad). Important to note is the intensity of septal fluting in the lateral slope areas. They form semicircular septal loops but in parallel sections, two adjacent septa seldom contact each other to form the "V-shaped" connection described earlier, even though their space is very narrow (Figs 3f, 3k). This species makes septal chamberlets in the lateral slope parts (Figs 3b-3c), but their nature is still incipient. These are good lines of evidence that the septa of $V$. transiens are indeed fluted but are not very intense, which would be described as "moderately fluted" at the most. Moreover, some random-sectioned specimens exhibit polar torsion at the axial ends (Figs 3a, 3e). Other morphological features to note are the relatively heavy development of the secondary deposits. In $V$. transiens, chomata are well discernible through growth, and axial fillings are relatively heavy (Villa \& Merino-Tomé, 2016). This species also exhibits slight tight coiling in the early one or two volutions, forming an indistinct juvenarium with relatively small to moderate proloculus (Figs 3g, 3j).

Higher up the section, separated by an about 240-m-thick siliciclastic-dominant interval from the sample level LT36, two samples (LT-42 and LT-44) in the fifth limestone interval of the Los Tornos section were originally placed at the top of the local zone IV, which is defined by the occurrence of Profusulinella rhomboides group, several typical Vereian Aljutovella species, and Verella transiens (Villa \& Merino-Tomé, 2016). Eofusulinine specimens available from these two samples yielded axial sections of immature individuals (Figs 3n, 3q, 3s), which are reminiscent of Verella transiens that lacks outermost one volution, by their very elongate fusiform shells. Moreover, they have slightly tightly coiled early volutions. But they show more intense septal fluting and less developed chomata, compared to the typical specimens of $V$. transiens from the second limestone interval. Additionally, some tangential-sectioned specimens (Figs 3p, 3r) from samples LT-42 and LT-44 show definitely stronger septal fluting than those of $V$. transiens, in forming distinct septal chamberlets in the axial parts and high and narrow septal loops in the lateral slopes. Thus, they can be related to Eofusulina rather than Verella, which more typically occurs from the next higher sample LT-45, and further higher limestone intervals of the Los Tornos section (Fig. 2b). Based on these morphological features, especially on the nature of stronger septal fluting, we judge that sample LT42 is the first appearance datum (FAD) of Eofusulina in the Los Tornos section (Figs 2, 4).

Of eofusulinines in higher levels (samples LT-45 to LT51), septal fluting becomes stronger and extends nearly over the entire shell except the central part of it; the proloculus becomes larger; and secondary deposits (chomata and axial fillings) become less developed. Moreover, there is no polar torsion and no early slightly tightly coiled volutions seen in Eofusulina sp. from the fifth to seventh limestone intervals (samples LT-42 to LT-51), which are observed in Verella transiens. Thus, specimens from samples LT-45 to LT-51 are clearly assignable to the genus Eofusulina, as Villa \& Merino-Tomé (2016) considered.

In the unerlying part of the Los Tornos section, Verella cf. normalis Rumyantseva, 1962 was reported from the upper part of the first limestone interval (the Peña Redonda Limestone in the basal part of the Levinco stratal package). This species is a typical, moderately evolved Verella, especially in its weaker septal fluting. Moreover, elsewhere in the Central Asturian Coalfield further ancestral Eowedekindellina species (E. solovievae Villa in Villa \& Merino-Tomé, 2016 and E. sp.) were reported from lower stratigraphic levels (in the local zones II and III) of the Santo Firme section located to the north of Oviedo (Villa \& Merino-Tomé, 2016). These species, together with Verella transiens and Eofusulina sp., are considered to form a single phylogenetic lineage in the Cantabrian Zone during late Bashkirian-early Moscovian time (Fig. 4).

We conclude that Verella and Eofusulina can be distinguished by the following features: 1) stronger septal fluting in Eofusulina, 2) lesser development of chomata in Eofusulina, 3) generally stronger axial fillings in Verella, 4) generally larger proloculus in Eofusulina, and 5) absence of inner tightly coiled volutions in Eofusulina. To the lesser extent, Eofusulina may have a slightly larger shell diameter and lacks polar torsion. No single character among these features, however, alone can be the conclusive diagnosis to distinguish these two genera, although as noted above, the degree and nature of septal fluting are important for identifying Eofusulina. The combination of all these morphological criteria substantially produces more reliable and stable identification of these genera. As a contribution to regional biostratigraphic aspects, this study slightly modified the result of Villa \& Merino-Tomé (2016) with respect to the first occurrence of Eofusulina in the Los Tornos section, and lowered it about $5 \mathrm{~m}$ stratigraphically, in the same fifth limestone interval of the section (compare fig. 6 in Villa \& Merino-Tomé (2016) and Fig. 4 in this study). More importantly, we have demonstrated the practical usefulness of tangential, parallel, and oblique sections, which usually are not paid much attention and thus are not illustrated often in the studies of fusuline taxonomy and classification. In some cases, these sections give us clues to understand morphological features that sometimes are not easily perceived based only on well-oriented axial and sagittal sections, such as the intensity (degree) of septal fluting and the presence of polar torsion. 


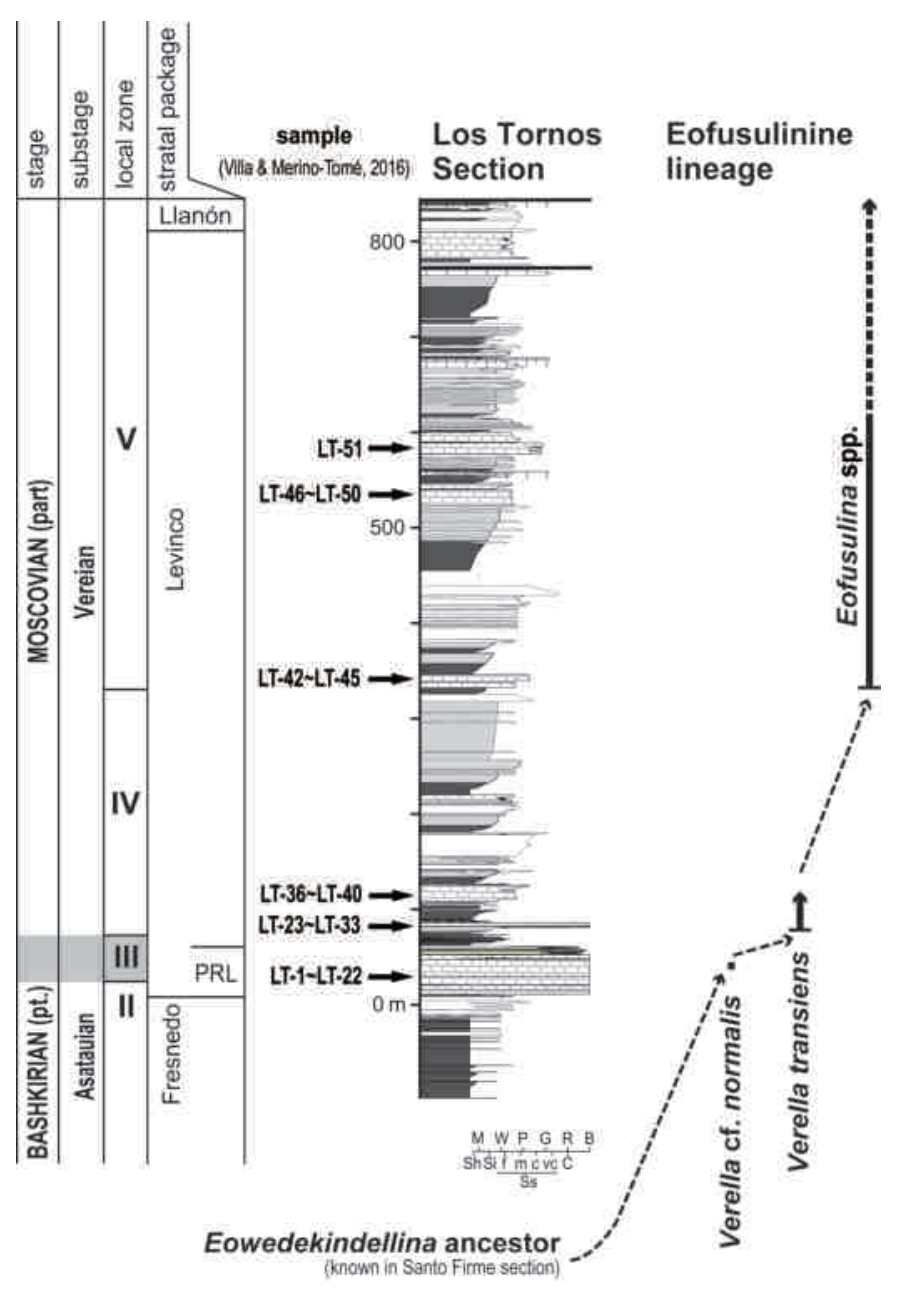

Figure 4. Diagram showing stratigraphic occurrences of eofusulinin species in the Los Tornos section (adapted from Villa \& Merino-Tomé, 2016). The first occurrence datum (FAD) of Eofusulina in the Los Tornos section is placed at sample LT-42 in the fifth limestone interval from the base of the section, following observation in this study. This level is about $5 \mathrm{~m}$ lower than the FAD of the genus presented by Villa \& Merino-Tomé (2016) originally. See Fig. 2 for the index of geologic $\log$ and other abbreviations.

\section{TAXONOMIC REVIEW OF VERELLA AND EOFUSULINA}

The genera Verella and Eofusulina are very peculiar in having elongate to highly elongate fusiform shells, among late Bashkirian-early Moscovian fusuline faunas, which are usually dominant in Pseudostaffella, Neostaffella, Profusulinella, Aljutovella, and Fusulinella with spherical, oval, ellipsoidal, rhomboidal, and fusiform shells. In spite of such noticeable morphology, however, these two eofusulinin genera tend to be represented as subordinate faunal elements because of their minor occurrences in the stratigraphic records (both in quantity and frequency). Accordingly their taxonomy is less progressed compared to coeval pseudostaffellin and fusulinellin genera mentioned above. On that account, we supplement to this article a systematic review of Verella and Eofusulina to describe their basic morphological features and taxonomic characterization.

\section{Superfamily Fusulinoidea von Möller, 1878}

Family Fusulinidae von Möller, 1878

Subfamily Eofusulininae Rauzer-Chernousova

\& Rozovskaya in Miklukho-Maklay, Rauzer-

Chernousova \& Rozovskaya, 1959

Genus Verella Dalmatskaya, 1951

1951 Verella Dalmatskaya, p. 195.

1958 Pseudowedekindellina Sheng, p. 29, 87-88.

1985 not Verella Goryunova, (established for a

Silurian bryozoan genus with Verella sytovae

Goryunova, 1985 as type species; junior homonym

of Verella Dalmatskaya, 1951)

Type species. Verella varsanofievae Dalmatskaya, 1951 (Fig. 1a). As discussed below, we deem the specific name varsanofievae as a correct original spelling of this taxon although Dalmatskaya (1951) originally spelled it as warsanofievie.

Diagnosis. Shell is medium-sized in eofusulinines, elongate to highly elongate fusiform with nearly straight to slightly curved axis of coiling, nearly straight to slightly convex lateral slopes, broadly arched to nearly flattened median part of shell, and bluntly pointed axial regions. It consists usually of up to around 5-5.5 volutions. Axis of coiling is constant, and early volutions are coiled slightly more tightly than outer volutions. Proloculus is spherical and relatively small to medium in size. Wall consists of a tectum, primatheca (lower less dense layer), and outer tectorium that may be discontinuous. Septa are numerous, nearly plane in early volutions but are weakly fluted in outer ones. They may be moderately fluted in mainly lateral slopes in outer volutions of some advanced forms, forming incipient septal chamberlets, but even in this case, septa become nearly plane in the central part of shell and extreme polar regions. Chomata are small and massive in inner volutions, but usually well discernible and asymmetrical in outer ones, extending gently toward axial regions and nearly vertical or overhanging to tunnel sides. Axial fillings are moderately developed in most forms. Tunnel is narrow to moderate. Polar torsion may be observed in some forms.

Discussion and remarks. As has been discussed by Villa \& Merino-Tome (2016), Verella is larger and has a more elongate shell with a slightly larger form ratio than 
its ancestral Eowedekindellina Ektova, 1977. Secondary deposits (axial fillings and upper tectorium) are more prominent in the latter genus. Moreover, Verella has weakly to moderately fluted septa, while they are essentially plane in Eowedekindellina.

Rozovskaya (1975), Sheng (1988), Rauzer-Chernousova et al. (1996), and Ivanova (2008) demonstrated that Pseudowedekindellina Sheng, 1958 (type species; Pseudowedekindellina prolixa Sheng, 1958; Fig. 1b) can be regarded as a junior synonym of Verella. Their essentially similar, elongate fusiform shells with weakly fluted septa, three-layered spirotheca, and late Bashkirian occurrences all support this interpretation.

Goryunova (1985) established the Silurian bryozoan genus Verella with $V$. sytovae Goryunova, 1985 as type species. In the same publication, she also described another species, $V$. kogulensis in the same bryozoan genus. That genus is, however, a junior homonym of fusuline Verella, which was established earlier, and thus the bryozoan genus Verella is regarded as invalid.

Siliculites was introduced by Fang (1988) in the subfamily Eofusulininae. Siliculites euchomaticus Fang, 1988 was designated as its type species, which came from the basal part of the Maping Formation of Guangxi, China. This level can be correlated to the Kasimovian (Late Pennsylvanian) as it contains Obsoletes, Montiparus, and Triticites. In the original description, that genus was compared to Verella, and also to Eofusulina to some extent, mainly because of its elongate fusiform shell and a similar spirothecal structure. Siliculites, however, is not regarded to be related to the eofusulinin lineage as its last member (Neofusulina Miklukho-Maklay, 1963) became extinct in a much lower level, at around the base of the late Moscovian (Leven, 1979). The gross shell morphology of Siliculites specimens illustrated by Fang (1988) suggests that it can possibly be referable to primitive schwagerinids, such as Montiparus, Schwageriniformis, or Triticites. Its apparent lack of keriothecal wall, which Fang (1988) considered diagnostic, is due probably to diagenetic alteration.

There is long-standing nomenclatural confusion about the correct spelling of the type species of Verella. Dalmatskaya (1951) originally named the type species as $V$. warsanofievie, dedicated to Вера Александровна Варсанофьева (Vera Aleksandrovna Varsanofieva). Later, Rauzer-Chernousova \& Dalmatskaya (1954) and MiklukhoMaklay et al. (1959) proposed two variant spellings for the scientific name of that species, which were both attributed to the original author and date; they are $V$. varsanofievae and $V$. warsanofievae. These modifications were based probably on correct latinization of its suffix (-ae for feminine) and moreover, widely accepted transliteration from Cyrillic into Roman alphabet (transcription of Cyrillic "B" into Roman "v", instead of "w"), but both are not justified under Article 32.5.1 of the International Code of Zoological Nomenclature (ICZN; International Commission on Zoological Nomenclature, 1999). Nevertheless the original spelling warsanofievie was seldom used in later publications (Thompson 1964 is the only instance in which we have found the use of the original spelling), while one of the two incorrect subsequent spellings, varsanofievae, has been definitely in prevailing usage since 1960s (Kireeva \& Dalmatskaya, 1960; Rumyantseva, 1962, 1974; MiklukhoMaklay, 1963; Beligovskiy \& Ektova, 1966; Saltovskaya, 1974; Rozovskaya, 1975; Dzhenchuraeva, 1975, 1979; Aliev et al., 1975; Granados et al., 1985; van Ginkel, 1987; Villa, 1995; Einor, 1996; Rauzer-Chernousova et al., 1996; Ivanova, 2000, 2008, 2015a, 2015b; Kim et al., 2007; Vodolazskaya et al., 2015; Kossovaya et al., 2016; Villa $\&$ Merino-Tome, 2016). The other subsequent incorrect spelling warsanofievae is lesser used (Yarikov, 1959; Pasini, 1965; Kahler \& Kahler, 1966; Toriyama, 1970; Rui, 1983; Loeblich \& Tappan, 1988; Sheng, 1988; Wang et al., 1992; Li \& Lin, 1994; Wang et al., 1995; Fan, 1998; Zhang et al., 2010). Consequently, in accordance with ICZN Articles 33.3.1 and 33.5, we here deem $V$. varsanofievae, which was originally used in Rauzer-Chernousova \& Dalmatskaya (1954), to be a correct original spelling for the taxonomic name of the type species of Verella.

As listed below, there have been some 30 species established in the genus Verella until now, in which Pseudowedekindellina fusiformis Sun in Sun et al., 1983 and Verella fusiformis Ivanova, 2000 are secondary and primary junior homonyms of $V$. fusiformis Bensh, 1969, respectively. We propose here $V$. zhenanensis, nomen novum for $P$. fusiformis Sun in Sun et al., 1983 and $V$. ivanovae, nomen novum for $V$. fusiformis Ivanova, 2000 as their new replacement names.

Species composition. Verella varsanofievae Dalmatskaya, 1951 (=V. warsanofievie Dalmatskaya, 1951 and V. warsanofievae Dalmatslaya, 1951); Verella spicata Dalmatskaya, 1951; Pseudowedekindellina prolixa Sheng, 1958; Verella acuminata Rumyantseva, 1962; Verella imperplana Rumyantseva, 1962; Verella normalis Rumyantseva, 1962; Verella bosdonica Rumyantseva, 1962; ?Verella plicata Rumyantseva, 1962; ?Verella fusiformis Bensh, 1969; Verella muruntavica Rumyantseva, 1974; Verella sparsaplicata Rumyantseva, 1974; Verella grandicamerata Saltovskaya, 1974; Eofusulina serrata Saltovskaya, 1974; Verella bashkirica Lebedeva in Stepanov et al., 1975; Verella binhaiensis Zhang \& Rui, 1980; Pseudowedekindellina antra Xie, 1982; Pseudowedekindellina paraprolixa Xie, 1982; Pseudowedekindellina? caudata Xie, 1982; ?Pseudowedekindellina obesa Zhang in Wang et al., 1982; Pseudowedekindellina fusiformis Sun in Sun et al., 1983 (secondary junior homonym of Verella fusiformis Bensh, 1969; = Verella zhenanensis, nomen novum); Verella guangdongensis Lin, 1983; Pseudowedekindellina lianpingensis Lin, 1983; Verella transiens van Ginkel 
\& Villa in van Ginkel, 1987; Pseudowedekindellina? zhungerensis Zhuang, 1990; Verella fuxianica Wang, Wang \& Zhang, 1992; Verella tarimensis Li \& Lin, 1994; Verella absidata Sun in Wang et al., 1995; Verella laxa Sun in Wang et al., 1995; Verella fusiformis Ivanova, 2000 (primary junior homonym of $V$. fusiformis Bensh, 1969; = Verella ivanovae, nomen novum).

The following two species should be excluded from Verella as they were established as bryozoan species: Verella sytovae Goryunova, 1985; Verella kogulensis Goryunova, 1985. In the course of scrutinizing literature, moreover, we found the following three taxonomic names; Verella kysilcumensis, Pseudowedekindellina yeongweolensis, and Pseudowedekindellina triangularis. The first one was found in Solovieva (1963) and the latter two are in Lee \& Na (1999). These taxa, if established formally, may have potential to be related to Verella in some way in the present taxonomy, but we could not find out their original references.

Distribution. Late Bashkirian and Bashkirian/ Moscovian transitional interval; Tethys province.

\section{Genus Eofusulina Rauzer-Chernousova in Rauzer- Chernousova, Kireeva, Leontovich, Gryzlova, Safonova \& Chernova, 1951}

1951 Eofusulina Rauzer-Chernousova in RauzerChernousova, Kireeva, Leontovich, Gryzlova, Safonova \& Chernova, p. 268-269.

1953 Akiyoshiella Toriyama, p. 251-253.

2008 Postverella Ivanova, p. 119-120.

Type species. Fusulina triangula Rauzer-Chernousova \& Beljaev in Rauzer-Chernousova, Beljaev \& Reitlinger, 1936 (Fig. 1c).

Diagnosis. Shell is medium to large in eofusulinines, elongate to highly elongate fusiform but rarely elongate ellipsoidal, with nearly straight to slightly curved axis of coiling, bluntly pointed axial regions, consisting usually of up to 4-5 volutions. Lateral slopes are straight to broadly convex. Shell expands gradually through growth, with constant axis of coiling. Proloculus is spherical but somewhat irregular in some forms, and mediumto large-sized (usually having $170-300 \mu \mathrm{m}$ in outside diameter). Wall consists of a tectum, primatheca (lower less dense layer), and thin outer tectorium which tends to be diminished in outer volutions. Primatheca may look slightly translucent. Septa are strongly and regularly to irregularly fluted from the first or second volution, forming narrow and high septal loops that may reach to nearly the roof of chamber, and septal chamberlets in the middle of axial regions on both sides of tunnel. Small chomata are seen in the inner volutions, and usually diminished or even absent in the outer ones, or probably replaced by pseudo-chomata. Axial fillings are usually weak to moderate, but often more prominent especially in the subgenus Paraeofusulina. Narrow to moderately broad tunnel is observed, but is unclear in some forms due to inconspicuous chomata.

Discussion and remarks. Eofusulina can be distinguished from its ancestral Verella in having stronger septal fluting, lesser development of secondary deposits, a generally larger proloculus, absence of inner tightly coiled volutions, and to some extent a slightly larger shell diameter and absence of polar torsion. However, in the case of the subgenus Paraeofusulina, secondary deposits, especially axial fillings, are even stronger than Verella.

Ueno in Fohrer et al. (2007) recognised strong similarities between Eofusulina and Akiyoshiella, which was established by Toriyama (1953) with A. ozawai Toriyama, 1953 (but probably conspecific with Schellwienia staffi Ozawa, 1925) from the Akiyoshi Limestone of Japan as type species (Fig. 1e). He provisionally retained that genus as distinct from Eofusulina, due mainly to the uncertain phylogenetic origin of the former within the mid-oceanic Panthalassa paleobiogeographical province. However, considering the close similarity of both morphologies and stratigraphic occurrences of these two genera, Akiyoshiella should now be better treated as a junior synonym of Eofusulina.

Postverella was established by Ivanova (2008), with Eofusulina figurata Ivanova in Chuvashov \& Ivanova (1980) from the Kashirian (upper Lower Moscovian; Middle Pennsylvanian) of the eastern slope of the Southern Urals, as type species (Fig. 1d). She noted that this genus can be distinguished from Eofusulina in having a smaller shell, three-layered wall, well-developed axial fillings, and mixed type of septal fluting, with plane septa in the first and second volutions but strongly fluted ones in the form of narrow and high loops in the subsequent volutions. However, all these features are considered to stay within the known morphological variations of Eofusulina. In this respect, we judge that Postverella is a junior synonym of Eofusulina.

Eofusulina can be subdivided into two subgenera: Eofusulina (s.s.) and Paraeofusulina Putrja, 1956 with the type species of Eofusulina (Paraeofusulina) trianguliformis Putrja, 1956 (Fig. 1f). The latter subgenus can be distinguished from the former by its more elongate shell, more compactly coiled volutions, usually slightly smaller proloculus, heavier axial fillings, and more regularly fluted septa with rounded septal loops.

Species composition. Subgenus Eofusulina (s.s.): Schellwienia staffi Ozawa, 1925; Fusulina triangula 
Rauzer-Chernousova \& Beljaev in Rauzer-Chernousova et al., 1936; Fusulina paratriangula Putrja, 1939; Fusulina triangula almasica Manukalova, 1950; Fusulina triangula finalis Manukalova, 1950; Akiyoshiella ozawai Toriyama, 1953; Akiyoshiella toriyamai Thompson, Pitrat \& Sanderson, 1953; Eofusulina binominata Putrja, 1956; Eofusulina inusitata Sheng, 1958; Eofusulina triangula fusiformis Grozdilova \& Lebedeva, 1960; Eofusulina corpulenta Rumyantseva, 1962; Verella postspicata Bensh, 1969; ?Verella postfusiformis Bensh, 1969; Eofusulina triangula gigas Bensh, 1969; ?Eofusulina crassa Saltovskaya, 1974; ?Eofusulina simplex Saltovskaya, 1974; Eofusulina rumjantzevae Lebedeva in Stepanov et al., 1975; Akiyoshiella fusulinoides Sosnina in Sosnina \& Nikitina, 1976; Eofusulina compacta Li in Lin et al., 1977; Eofusulina pullata Ivanova in Chuvashov \& Ivanova, 1980; Eofusulina figurata Ivanova in Chuvashov \& Ivanova, 1980; Eofusulina? dualis Ivanova in Chuvashov \& Ivanova, 1980; Eofusulina tashlensis Malakhova, 1980 (nomen nudum; probably included in E. triangula); Eofusulina fenghuangshanensis Wang, 1981; Eofusulina longipertica Lin in Wang et al., 1982; Eofusulina xinjiangensis Sun in Da \& Sun, 1983; Eofusulina hamiensis Sun in Da \& Sun, 1983; Eofusulina megatriangula Sun in Da \& Sun, 1983; Eofusulina triangula minima Da in Da \& Sun, 1983; Eofusulina tumidoformis Sun, 1992; Akiyoshiella irregularis Lee in Lee \& Park, 1994. Moreover, we add one potential nude-name taxon to this subgenus; Eofusulina tetis Solovieva (MS), which was found in Dzhenchuraeva (1979, text-fig. 3, pl. 37, figs 4, 5). This is probably the same as Eofusulina triangula tethys Solovieva, illustrated by Orlov-Labkovsky \& Bensh (2015, pl. 33, figs 8, 9; pl. 37, fig. 2). Eofusulina fortis Zhuang, 1984 and Eofusulina duijiugouensis Zhuang, 1990 were originally assigned to this subgenus, but should be included in Quasifusulina and Beedeina (or Fusulina), respectively.

Subgenus Eofusulina (Paraeofusulina): Fusulina triangula rosdorica Putrja, 1938; Eofusulina (Paraeofusulina) trianguliformis Putrja, 1956; Paraeofusulina quadratoarcus Rumyantseva, 1974; Eofusulina angusta Saltovskaya, 1974; Eofusulina arcuata Saltovskaya, 1974. Three species of this subgenus reported by Zhuang (1984), Eofusulina (Paraeofusulina) quasifusulinoides, Eofusulina (Paraeofusulina) subcylindrica, and Eofusulina (Paraeofusulina) guizhouensis, should be included in Quasifusulina by their basic morphologies.

Distribution. Lower Moscovian; Tethys, Panthalassa, Ural, and Arctic provinces.

\section{ACKNOWLEDGEMENTS}

We would like to dedicate the present article to Profs. Luis C. Sánchez de Posada (Suco) and María Luisa Martínez Chacón (Lis) for their long-standing versatile contributions to the stratigraphy and palaeontology of the Carboniferous System. They have always been excellent mentors for our researches on this discipline. We thank Prof. Aleksandra V. Dzhenchuraeva for her nomenclatural information about Eofusulina tetis, and Dr. Paul L. Brenckle for his valuable instruction on the International Code of Zoological Nomenclature. We are also grateful to Drs. Gregory P. Wahlman and Svetlana T. Remizova for their useful review comments that have improved the final version of the manuscript. This study was performed during sabbatical stay of the senior author at the University of Oviedo in 2016. He thanks Fukuoka University for permitting the stay.

\section{REFERENCES}

Aliev, M.M., Yarikov, G.M., Khachatryan, R.O., Vissarionova, A.Ya., Kuznetsov, Yu.I., Semenova, E.G., Siestnova, L.P., Travina, L.M. \& Shelinova, A.K. 1975. Kamennougol'nye Otlozheniya Volgo-Ural'skoy Neftegazonosnoy Provintsii. Ministerstvo Neftyanoy Promyshlennosti, Akademiya Nauk SSSR, Institut Geologii i Razravotki Goryuchikh Iskopaemykh, Nedra, Moskva (in Russian).

Alonso, J.L., Marcos, A. \& Suárez, A. 2009. Paleogeographic inversion resulting from large out of sequence breaching thrusts: The León Fault (Cantabrian Zone, NW Iberia). A new picture of the external Variscan Thrust Belt in the Ibero-Armorican Arc. Geologica Acta, 7, 451-473.

Beligovskiy, G.L. \& Ektova, L.A. 1966. O granitse bashkirskogo i moskovskogo yarusov v Tyan'-Shane. Doklady Akademii Nauk SSSR, 169, 1389-1391 (in Russian).

Bensh, F.S. 1969. Stratigrafiya i Foraminifery Karbona Yuzhnogo Gissara. Akademiya Nauk Uzbekskoy SSR, Institut Geologii i Geofiziki im. Kh. M. Abdullaeva, Izdatel'stvo FAN, Uzbekskoy SSR, Tashkent (in Russian).

BouDagher-Fadel, M.K. 2008. Evolution and Geological Significance of Larger Benthic Foraminifera. Developments in Palaeontology \& Stratigraphy 21, Elsevier, Amsterdam.

Chuvashov, B.I. \& Ivanova, R.M. 1980. Moskovskie i verkhnekamennougol'nye otlozheniya v razreze «UlyTaldyk» (Vostochnye Mugodzhary). In: Stratigrafiya, Fuzulinidy i Miospory Karbona Urala (eds. Papulov, G.N. \& Pakhomov, I.V.). Akademiya Nauk SSSR, Ural'skiy Nauchnyy Tsentr, Sverdlovsk, 94-117 (in Russian).

Da, Y.T. \& Sun, Q.L. 1983. Fusulinida. In: Paleontological Atlas of Northwest China, Xinjiang Weiwuer Autonomous Region, Volume 2 (Late Paleozoic) (chiefly ed. Regional Geology Surveying Team of Xinjiang). Geological Publishing House, Beijing, 7-113 (in Chinese). 
Dalmatskaya, I.I. 1951. Novyy rod fuzulinid iz nizhney chasti srednekamennougol'nykh otlozheniy Russkoy platformy. Trudy Moskovskogo Obshchestva Ispytateley Prirody, 1 (Otdel Geologicheskiy), 194-196 (in Russian).

Davydov, V.I. 1988. About a phylogenetic criterion of weighing specific features in foraminifer systematics (exemplified by fusulinids). Revue de Paléobiologie, Volume Spécial, 2 (Proceedings of Benthos' 86), 47-55.

Davydov, V.I. 1990. K utochneniyu proiskhozhdeniya i filogenii trititsitesov i granitzy srednego i verkhnego otdelov Karbona. Paleontolohicheskiy Zhurnal, 1990, 13-25 (in Russian).

Dunbar, C.O. \& Henbest, L.G. 1942. Pennsylvanian Fusulinidae of Illinois. Illinois Geological Survey, Bulletin, 67, 1-218.

Dzhenchuraeva, A.V. 1975. O batimetricheskoy zonal'nosti srednekamennougol'nykh fuzulinid Turkestano-Alaya. Akademiya Nauk SSSR, Voprosy Mikropaleontologii, 18, 74-95 (in Russian with English abstract).

Dzhenchuraeva, A.V. 1979. Stratigrafiya i Foraminifery Srednekamennougol'nykh Otlozheniy Severnykh Sklonov Turkestano-Alaya. Izdatel'stvo Ilim, Furnze (in Russian).

Einor, O.L. 1996. The former USSR. In: The Carboniferous of the World, III. The Former USSR, Mongolia, Middle Eastern Platform, Afghanistan, \& Iran (eds. Wagner, R.H., Winkler Prins, C.F. \& Granados, L.F.). Instituto Tecnológico Geominero de España (ITGE), Madrid and Nationaal Natuurhistorisch Museum, Leiden, 13-407.

Ektova, L.A. 1977. Novyy rod fuzulinid Eowedekindellina i ego sistematicheskoe polozhenie. Akademiya Nauk SSSR, Ezhegodnik Vsesoyuznogo Paleontologicheskogo Obshchestva, 20, 35-48 (in Russian).

Fan, G.Q. 1998. Research on the Carboniferous Stratigraphy and Biota in South of Northeast China. Seismological Press, Beijing (in Chinese).

Fang, H.Y. 1988. Fusulinids from the Maping Formation of Longhuo, Longlin, Guangxi. Acta Micropalaeontologica Sinica, 5, 403-414 (in Chinese with English abstract and description of new species).

Fohrer, B., Nemyrovska, T.I., Samankassou, E. \& Ueno, K. 2007. The Pennsylvanian (Moscovian) Izvarino Section, Donets Basin, Ukraine: A multidisciplinary study on microfacies, biostratigraphy (conodonts, foraminifers, and ostracodes), and paleoecology. Memoir, the Paleontological Society, 69 (Supplement to Journal of Paleontology, Volume 81, No. 5), 1-85.

Ginkel, A.C., van 1987. Systematics and biostratigraphy of fusulinids of the Lena Formation (Carboniferous) near Puebla de Lillo (León, NW Spain). Proceedings of the Koninklijke Nederlandse Akademie van Wetenschappen, Series B, 90, 189-276.

Goryunova, R.V. 1985. Morfologiya, sistema i filogeniya mushanok. Akademiya Nauk SSSR, Trudy Paleontologicheskogo Instituta, 208, 1-152 (in Russian).

Granados, L.F., Solovieva, M.N., Reitlinger, E.A. \& MartínezDíaz, C. 1985. The Bashkirian-Moscovian boundary problem in the Asturias (Northwest Spain). In: Dixième Congrès International de Stratigraphie et de Géologie du Carbonifère (Madrid, 1983), Compte Rendu, Volume 1 (eds. Escobedo, J.L., Granados, L.F., Meléndez, B., Pignatelli, R., Rey, R. \& Wagner, R.H.). Instituto Geológico y Minero de España, Madrid, 27-34.

Groves, J.R. 2005. Fusulinid wall structure in the Profusulinella-Fusulinella evolutionary transition. In: A Standing Ovation: Papers in Honor of Gilbert Klapper (eds. Barrick, J.E. \& Lane, H.R.). Bulletin of American Paleontology, 369, 199-218.

Groves, J. \& Task Group 2011. Report of the task group to establish a GSSP close to the existing BashkirianMoscovian boundary. Newsletter on Carboniferous Stratigraphy, 29, 30-33.

Grozdilova, L.P. \& Lebedeva, N.S. 1960. Foraminifery kamennougol'nykh otlozheniy zapadnogo sklona Urala i Timana (Atlas naibolee kharakternykh vidov). Trudy Vsesoyuznogo Neftyanogo Nauchno-Issledovatel'skogo Geologorazvedochnogo Instituta (VNIGRI), 150, 1-264 (in Russian).

International Commission on Zoological Nomenclature. 1999. International Code of Zoological Nomenclature, Fourth Edition. The International Trust for Zoological Nomenclature, London.

Ivanova, R.M. 2000. New taxa of foraminifera from the Bashkirian of the Urals. Paleontological Journal, 34, 147-154.

Ivanova, R.M. 2008. Fuzulinidy i Vodorosli Srednego Karbona Urala: Zonal'naya Stratigtafiya, Paleobiogeografiya, Paleontologiya. Rossiyskaya Akademiya Nauk, Ural'skoe Otdelenie, Institut Geologii i Geokhimii im. Akad. A. N. Zavaritskogo, Ekaterinburg (in Russian).

Ivanova, R.M. 2015a. Evolyutsiya eofuzulinin i ikh rod' V stratigrafii srednego karbona Urala. Russiyskaya Akademiya Nauk, Ural'skoe Otlozhenie, Institut Geologii i Geokhimii im. Akad. A. N. Zavaritskogo, Litosfera, 2015 (5), 105-109 (in Russian with English abstract).

Ivanova, R.M. 2015b. Biostratigraficheskaya rol' i evolyutsiya eofuzulinin v srednem karbone Urala. In: Sovremennaya Mikropaleontologiya: Sbornik Trudov XVI Vserossiyskogo Mikropaleontologicheskogo Soveschaniya, Kaliningrad, 2015 (eds. Vishnevskaya, V.S. \& Olshanetsky, D.M.). Atlanticheskim Otdeleniem Federal'nogo Gosudarstvennogo Byudzhetnogo Uchrezhdeniya Nauki Instituta Okeanologii im. P. P. Shirshova (AO IO, RAN), Kaliningrad, 213-216 (in Russian).

Kahler, F. \& Kahler, G. 1966. Fusulinida (Foraminiferida), Teil 2 (Fossilium Catalogus. I: Animalia, Pars 112). Uitgeverij Dr. W. Junk, 's-Gravenhage.

Kim, A.I., Salimova, F.A., Kim, I.A. \& Meshchankina, N.A. (eds.) 2007. Palaeontological Atlas of Phanerozoic Faunas and Floras of Uzbekistan, Volume I. Palaeozoic (Cambrian, Ordovician, Silurian, Devonian, Carboniferous, Permian). Republic of Uzbekistan State Committee on Geology and Mineral Resources, Tashkent.

Kireeva, G.D. \& Dalmatskaya, I.I. 1960. K voprosu o stratigrafii Bashkirskogo yarusa. Izvestiya Akademii Nauk SSSR, Seriya Geologicheskaya, 1960 (9), 29-40 (in Russian). 
Kossovaya, O.L., Isakova, T.N., Sungatullina, G.M. \& Kukhtinov, D.A. 2016. Maket regional'noy stratigraficheskoy skhemy srednego-verkhnego Karbona Volgo-Ural'skogo subregiona. In: Sostoyanie Stratigraficheskoy Bazy Tsentra i Yugo-Vostoka VostochnoEvropeyskoy Platformy (Regional'noe Stratigraficheskoe Soveschanie) (ed. Varlamova, E.A.). Federal'noe Gosudarstvennoe Byudzhetnoe Uchrezhdenie, Vserossiyskiy Nauchno-Issledovatel'skiy Geologicheskiy Neftyanoy Institut (FGBU, VNIGNI), Laksheri Print, Moskva, 64-71 (in Russian).

Lee, C.Z. \& Na, K.W. 1999. Fusulinacean biostratigraphy and phylogeny from the Yobong Limestone near the Daerim Coalmine-Jeopsan area, Yeongweol-gun, Korea. The Journal of the Korean Earth Science Society, 20, 469-475 (in Korean with English abstract).

Lee, C.Z. \& Park, S.I. 1994. Some fusulinids from the Gapsan Formation near Jecheon, Korea. The Journal of the Korean Earth Science Society, 15, 452-458.

Leven, E.Ya. 1979. The systematics of the subfamily Eofusulininae. Paleontological Journal, 13, 255-258.

Li, L.Z. \& Lin, J.X. 1994. Fusulinida. In: Stratigraphy and Palaeontology of Oil and Gas Bearing Area in China, Sinian to Permian Stratigraphy and Palaeontology of the Tarim Basin, Xinjiang. III, Tieklik Region (eds. Southern Xinjiang Petroleum Prospecting Cooperation, Xinjiang Petroleum Administration Bureau \& Jianghan Petroleum Institute). The Petroleum Industry Press, Beijing, 71-107 (in Chinese and English).

Lin, J.X. 1983. Fusulinids from the lower Upper Carboniferous Huanglong Formation in Guangdong. Bulletin of the Chinese Academy of Geological Sciences, 7, 87-98 (in Chinese with English abstract).

Lin, J.X., Li, J.X., Chen, G.X., Zhou, Z.R. \& Zhang, B.F. 1977. Fusulinida. In: Paleontological Atlas of Central South China, 2 (Late Paleozoic) (eds. Hubei Institute of Geological Science, Geological Bureau of Henan Province, Geological Bureau of Hubei Province, Geological Bureau of Hunan Province, Geological Bureau of Guangdong Province \& Geological Bureau of Guangxi Zhuangzu Autonomous Region). Geological Publishing House, Beijing, 4-96 (in Chinese).

Loeblich, A.R., Jr. \& Tappan, H. 1988. Foraminiferal Genera and Their Classification. Van Nostrand Reinhold, New York.

Malakhova, N.P. 1980. Srednekamennougol'nye Fuzulinidy Yugo-vostochnogo Urala. Akademiya Nauk SSSR, Ural'skiy Nauchnyy Tsentr, Institit Geologii i Geokhimii im. Akad. A. N. Zavaritskogo, Sverdlovsk (in Russian).

Manukalova, M.F. 1950. Novye vidy fuzulinid iz izvestnyakov srednego karbona Donbassa. In: Geologo-Issledovatel'skie Raboty, Materialy po Stratigrafii i Paleontologii Donetskogo Basseyna (ed. Kuznetsov, N.A.). Ministterstvo Ugol'noy Promyshlennosti SSSR, Glavnoe Upravlenie po Razvedokam Uglya, Ugletekhizdat, Moskva, 219-237 (in Russian).

Miklukho-Maklay, A.D. 1963. Verkhniy Paleozoy Sredney Azii. Leningradskiy Ordena Lenina Gosudarstvennyy Universitet im. A. A. Zhdanova, Izdatel'stvo Leningradskogo Universiteta, Leningrad (in Russian).

Miklukho-Maklay, A.D., Rauzer-Chernousova, D.M. \& Rozovskaya, S.E. 1959. Otryad Fusulinida. In: Osnovy Paleontologii, Spravochnik dlya Paleontologiv i Geologov SSSR, Obshchaya Chast' Prosteyshie (eds. RauzerChernousova, D.M. \& Fursenko, A.V.). Izdatelstvo Alademii Nauk SSSR, Moskva, 201-215 (in Russian).

Möller, V., von 1878. Die spiral-gewundenen Foraminiferen des Russischen Kohlenkalks. Mémoires de l'Académie Impériale des Sciences de St.-Pétersbourg, 7ème Série, $25,1-147$.

Orlov-Labkovsky, O. \& Bensh, F.R. 2015. Atlas of Foraminifera of the Carboniferous and Permian (Cisuralian) of Uzbekistan and Adjacent Regions, Tien Shan. PENSOFT, Sofia-Moscow.

Ozawa, T. 1970. Notes on the phylogeny and classification of the superfamily Verbeekinoidea (Studies of the Permian verbeekinoidean foraminifera-I). Memoirs of the Faculty of Science, Kyushu University, Series D, Geology, 20, $17-58$.

Ozawa, T. 1975. Evolution of Lepidolina multiseptata (Permian foraminifer) in East Asia. Memoirs of the Faculty of Science, Kyushu University, Series D, Geology, 23, 117-164.

Ozawa, Y. 1925. Paleontological and stratigraphical studies on the Permo-Carboniferous limestone of Nagato. Part II, Paleontology. Journal of the College of Science, Imperial University of Tokyo, 45, 1-90.

Pasini, M. 1965. Fusulinidi, una Chiave Analitica per la Determinazione dei Generi. Palaeontographica Italica, Pisa.

Putrja, F.S. 1938. Rezul'taty mikropaleontologicheskoy obrabotki kernov iz burovykh skvazhin rayona stanitsy Razdorskoy na Donu. Azovo-Chernomorskiy Geologicheskiy Trest, Materialy po Geologii i Poleznym Iskopaemym, 2, 17-28 (in Russian).

Putrja, F.S. 1939. K izucheniyu srednekamennougol'nykh foraminifer v Donetskom basseyne. Azovo-Chernomorskoe Geologicheskoe Upravlenie, Materialy po Geologii $i$ Poleznym Iskopaemym, 8, 175-187 (in Russian).

Putrja, F.S. 1956. Stratigrafiya i foraminifery srednekamennougol'nykh otlozheniy vostochnogo Donbassa. Trudy Vsesoyuznogo Neftyanogo NauchnoIssledovatel'skogo Geologorazvedochnogo Instituta (VNIGRI), Novaya Seriya, 98 (Mikrofauna SSSR, Sbornik 8), 333-519 (in Russian).

Rauzer-Chernousova, D.M. \& Dalmatskaya, I.I. 1954. Stratigrafiya i foraminifery srednekamennougol'nykh otlozheniy yugo-vostochnoy okrainy Moskovskoy Sineklizy (Tokmovskiy Svod). In: Stratigrafiya Srednekamennougol'nykh Otlozheniy Tsentral'noy $i$ Vostochnoy Chastey Russkoy Platformy (Na Osnove Izucheniya Foraminifer). 1. Moskovskaya Sinekliza (ed. Menner, V.V.) (Akademiya Nauk SSSR, Institut Geologicheskikh Nauk, Regional'naya Stratigrafiya SSSR, 2). Izdatel'stvo Akademii Nauk SSSR, Moskva, 201-254 (in Russian). 
Rauzer-Chernousova, D.M., Beljaev, G.M. \& Reitlinger, E.A. 1936. Verkhne-Paleozoyskie foraminifery Pechorskogo kraya. Akademiya Nauk SSSR, Trudy Polyarnoy Komissii, 28, 159-232 (in Russian with German summary and description of new genus and species).

Rauzer-Chernousova, D.M., Kireeva, G.D., Leontovich, G.E., Gryzlova, N.D., Safonova, T.P. \& Chernova, E.I. 1951. Srednekamennougol'nye Fuzulinidy Russkoy Platformy $i$ Sopredel'nykh Oblastey. Akademiya Nauk SSSR, Institut Geologicheskikh Nauk, Ministerstvo Neftyanoy Promyshlennosti SSSR, Izdatelstvo Akademii Nauk, Moskva (in Russian).

Rauzer-Chernousova, D.M., Bensh, F.S., Vdovenko, M.V., Gibshman, N.B., Leven, E.Ya., Lipina, O.A., Reitlinger, E.A., Solovieva, M.N. \& Chediya, I.O. 1996. Sprabochnik po Sistematike Foraminifer Paleozoya (Endotiroidy, Fuzulinidy). Rossiyskaya Akademiya Nauk, Geologicheskiy Institut, Nauka, Moskva (in Russian).

Rozovskaya, S.E. 1975. Sostav, sistema i filogeniya otryada Fuzulinida. Akademiya Nauk SSSR, Trudy Paleontologicheskogo Instituta, 149, 1-267 (in Russian).

Rui, L. 1983. Fusulinacean fauna from the Quanwangtou Limestone (early Upper Carboniferous) in Jiawang coalfield, Northern Jiangsu. Acta Palaeontologica Sinica, 22, 170-181 (in Chinese with English abstract).

Rumyantseva, Z.C. 1962. Novye vidy fuzulinid srednego karbona tsentral'nykh Kyzylkumov. In: Stratigrafiya $i$ Paleontologiya Uzbekistana i Sopredel'nykh Rayonov (ed. Chernyavskaya, A.B). Glavgeologiya Uzbekskoy SSR, Institut Geologii AN Uzbekskoy SSR, Tashkent, 169-185 (in Russian).

Rumyantseva, Z.C. 1974. Stratigrafiya i Foraminifery Srednego Karbona Tsentral'nykh Kyzylkumov. Ministerstvo Geologii Uzbekskoy SSR, Sredneaziatskiy NauchnoIssledovatel'skiy Institut Geologii i Mineral'nogo Syr'ya (SAIGIMS), Izdatel'stvo FAN, Uzbekskoy SSR, Tashkent (in Russian).

Saltovskaya, V.D. 1974. Stratigrafiya Kamennougol'nykh Otlozheniy Zeravshano-Gissarskoy Gornoy Oblasti. Akademiya Nauk Tadzhikskoy SSR, Institut Geologii, Izdatel'stvo "Donish", Dushanbe (in Russian).

Sheng, J.C. (Sheng, J.Z.) 1958. Fusulinids from the Penchi Series of the Taitzeho valley, Liaoning. Palaeontologia Sinica, 143 (New Series B, No. 7), 1-119 (in Chinese and English).

Sheng, J.Z. 1988. Fusulinids. Science Publishing House, Beijing (in Chinese)

Solovieva, M.N. 1963. Stratigrafiya i fuzulinidovye zony srednekamennougol'nykh otlozheniy Sredney Azii. Akademiya Nauk SSSR, Trudy Geologicheskogo Instituta, 76, 1-134 (in Russian).

Sosnina, M.I. \& Nikitina, A.P. 1976. Kamennougol'nye foraminifery Primor'ya. Ministerstvo Geologii SSSR, Trudy Vsesoyuznyy Ordena Lenina Nauchno-Issledovatel'skiy Geologicheskiy Institut (VSEGEI), Novaya Seriya, 247 (Stratigrafiya i Paleontologiya Karbona), 16-69 (in Russian).
Stepanov, D.L., Krylova, A.K., Grozdilova, L.P., Pozner, V.M. \& Sultanaev, A.A. 1975. Paleontologicheskiy atlas kamennougol'nykh otlozheniy Urala. Trudy Vsesoyuznyy Neftyanoy Nauchno-Issledovatel'skiy Geologorazvedochnyy Institut (VNIGRI), 383, 1-359 (in Russian).

Sun, H.F., Gao, C.X. \& Zhang, L.X. 1983. Fusulinida. In: Paleontological Atlas of Northwest China, Shaanxi, Gansu and Ningxia Volume, Part 2 (Upper Palaeozoic) (ed. Xi'an Institute of Geology and Mineral Resources). Geological Publishing House, Beijing, 3-40 (in Chinese).

Sun, H.Y. 1992. Fusulinida. In: Paleontological Atlas of Jilin Province (chiefly ed. Bureau of Geology and Mineral Resources of Jilin Province). Jilin Science and Technology Press, Changchun, 44-129 (in Chinese).

Thompson, M.L. 1964. Fusulinacea. In: Treatise on Invertebrate Paleontology (ed. Moore, R.C.), Part C, Protista 2. Sarcodina chiefly "Thecamoebians" and Foraminiferida (eds. Loeblich, A.R., Jr. \& Tappan, H.). Geological Society of America, Boulder and University of Kansas Press, Lawrence, 358-436.

Thompson, M.L., Pitrat, C.W. \& Sanderson, G.A. 1953. Primitive Cache Creek fusulinids from central British Columbia. Journal of Paleontology, 27, 545-552.

Toriyama, R. 1953. New peculiar fusulinid genus from the Akiyoshi Limestone of southwestern Japan. Journal of Paleontology, 27, 251-256.

Toriyama, R. 1970. Fusulinida. In: Micropaleontology, First Volume (ed. Asano, K.). Asakura-shoten, Tokyo, 201-259 (in Japanese).

Villa, E. 1995. Fusulináceos carboníferos del este de Asturias (N de España). Biostratigraphie du Paléozoique, 13, $1-261$.

Villa, E. \& Merino-Tomé, O. 2016. Fusulines from the Bashkirian/Moscovian transition in the Carboniferous of the Cantabrian Zone (NW Spain). Journal of Foraminiferal Research, 46, 237-270.

Vodolazskaya, V.P., Teterin, I.P., Kirillov, V.A., Lukiyanova, L.I., Petrov, G.A., Stefanovskiy, V.V., Morozov, G.G., Zhdanov, A.V., Zhizanov, A.V., Stryapunina, E.V., Esikin, A.G., Petrova, T.A., Verbichkiy, I.V. \& Verbichkaya, N.V. 2015. Gosudarstvennaya Geologicheskaya Karta Rossiyskoy Federatsii. Masshtab 1:1,000,000 (Tret'e Pokolenie). Seriya Ural'skaya, List O-40-Perm', Ob'yasnitel'naya Zapiska. Federal'noe Gosudarstvennoe Unitarnoe Predpriyatie, Vserossiyskiy Nauchno-Issledovatel'skiy Geologicheskiy Institut im. A. P. Karpinskogo (FGUP, VSEGEI), Kartograficheskaya Fabrika VSEGEI, SanktPeterburg (in Russian).

Wang, L.L. 1981. Some new species of fusulinids from the Carboniferous-Permian of Anhui, China. Acta Palaeontologica Sinica, 20, 127-137 (in Chinese with English abstract).

Wang, X.Z., Sun, S.D., Yu, B.Z., Zeng, Z.Y., Sun, D.M., Li, C.W., Wang, K.P., Liu, F.J., Lu, Q.Y. \& Li, Z.Q. 1995. Late Paleozoic Coal-bearing Stratigraphy and Biota of Xuzhou Area. Beijing Science and Technology Press, Beijing (in Chinese). 
Wang, Y.H., Wang, L.L., Wang, J.H., Zhu, Z.G., Lin, G.W., Zhang, L.X. \& Quian, Q. 1982. Fusulinida. In: Paleontological Atlas of East China, 2 (Volume of Late Paleozoic) (chiefly ed. Nanjing Institute of Geology and Palaeontology). Geological Publishing House, Beijing, 5-108 (in Chinese).

Wang, Z.Y., Wang, Y.H. \& Zhang, L.X. 1992. Profusulinella fauna from the Fuzhou Gulf of Liaoning. Acta Micropalaeontologica Sinica, 9, 415-421 (in Chinese with English summary and description of new species).

Xie, S.G. 1982. Protozoa. In: The Palaeontological Atlas of Hunan (ed. Geological Bureau of Hunan). Geological Publishing House, Beijing, 2-73 (in Chinese).

Yarikov, G.M. 1959. Kamennougol'nye otlozheniya basseina nizhnego techeniya r. Khopra. Geologiya Nefti i Gaza, 1959 (9), 43-50 (in Russian).

Zhang, L.X. \& Rui, L. 1980. Fusulinids from the Binhai Xian, northern Jiangsu. Acta Palaeontologica Sinica, 19, 321-326 (in Chinese with English abstract).
Zhang, L.X., Zhou, J.P. \& Sheng, J.Z. 2010. Upper Carboniferous and Lower Permian fusulinids from western Guizhou. Palaeontologia Sinica, 195 (New Series B, No. 34), 1-296 (in Chinese with English summary and description of new species).

Zhuang, S.Q. 1984. Fusulinids from the Maping Group, at Dala of Panxian, Guizhou. Journal of China Institute of Mining and Technology, 1984 (1), 59-74 (in Chinese with English abstract).

Zhuang, S.Q. 1990. Description of fusulinids. In: Research on the Late Paleozoic Coal-bearing Stratigraphy and Biota in Jungar, Nei Mongol (Inner Mongolia) (eds. He, X.L., Zhang, Y.J., Zhu, M.L., Zhang, G.Y., Zhuang, S.Q., Zeng, Y. \& Song, P.). China University of Mining \& Technology Press, Xuzhou, 109-204 (in Chinese with English summary and description of new species). 